\title{
Calcium Composition and Microstructure of Coral Stylophora pistillata under Phosphate Pollution Stress in the Gulf of Aqaba
}

\author{
Ali Al-Sawalmih ${ }^{1,2}$ \\ ${ }^{1}$ Marine Science Station, The University of Jordan \& Yarmouk University, Aqaba, Jordan \\ ${ }^{2}$ Department of Coastal Environment, Faculty of Marine Sciences, The University of Jordan, Aqaba, Jordan \\ Email: a.sawalmih@ju.edu.jo
}

Received 8 February 2016; accepted 4 March 2016; published 7 March 2016

Copyright (C) 2016 by author and Scientific Research Publishing Inc.

This work is licensed under the Creative Commons Attribution International License (CC BY). http://creativecommons.org/licenses/by/4.0/

(c) (i) Open Access

\begin{abstract}
Corals and coral-reef ecosystems have been known to be extremely sensitive to environmental pollution, which effects on growth and calcification of their skeletons. Diffused phosphate dust during loading and shipment in seawater was found to cause serious impacts on corals by inhibiting calcification in their skeletons. Calcium concentrations in cultured fragments of coral Stylophora pistillata from Phosphate Terminal (PT) site in the Jordanian Gulf of Aqaba were investigated and compared with fragments from the same colony cultured in the Marine Science Station (MSS) site as marine protected area. Energy Disperse X-rays (EDX) spectroscopy and Scanning Electron Microscopy (SEM) were employed to determine the elemental composition of coral fragments and identify their microstructural characteristics, respectively. EDX results showed that coral samples from the Phosphate Terminal (PT) site were poorly mineralized with significantly low concentrations of calcium which were only about $12 \%$ of those from the MSS control site. Moreover, higher amounts of $O$ and $C$ in the elemental analysis of corals from the PT site indicated domination of organic matrix content in their skeleton which is typical for corals under phosphate pollution stress. This result was in accordance with the SEM images of the PT samples which exhibited alteration in their microstructure morphology resembling organic matrix as a major constituent, unlike the SEM images from the MSS protected area. These results strongly suggest that phosphate dust which is diffused during exportation through loading and shipping in the Gulf of Aqaba has adverse impacts on corals and marine ecosystem through decreasing calcium mineralization in their skeletons.
\end{abstract}

\section{Keywords}

Phosphate, Coral, Gulf of Aqaba, Calcification, Stylophora pistillata, EDX, SEM 


\section{Introduction}

Coral reef ecosystems were found to be highly sensitive to changes in the surrounding physicochemical environment [1]. Coastal coral reefs are increasingly exposed to growing loads of nutrients, sediments and pollutants which made terrestrial and coastal runoff a growing concern for most of the 104 countries endowed with coral reefs [2] [3]. Moreover, using and handling of fertilizer that contains phosphate has led to change of seawater quality in coastal areas [4] [5].

The Jordanian coastline is only $27 \mathrm{~km}$ long, and lies in one of the most important economic development districts in Jordan. Due to high rates of industrial developments, population growth, and tourism, the Gulf of Aqaba has been heavily impacted by human activities, especially along its northern part [6]. The export in the port of Aqaba is dominated by the phosphates [7], and the Port Corporation of Aqaba operates a large Phosphate export facility that is capable of loading 2200 tons of material per hour [8].

Loading phosphate of ships with conventional loading systems resulted in very high levels of dust pollution [9]. Phosphate is an extremely dry and dusty material and is produced as a constituent of fertilizer. Much of the dust settles into the sea leading to increasing phosphate concentrations in seawater due to its high solubility [10] [11]. Phosphate dust in Aqaba seawater is soluble over the annual water temperature range and some algae may be able to solubilize particulate phosphate [12] [13].

Pollution by mineral phosphate dust as a consequence of inefficient loading of crushed phosphate rock [14] leads to increase of eutrophication in seawater, which affects survival and stability of reef communities [15][18], with additional response of widespread coral death.

Phosphate and phosphate-containing organics are known as inhibiters of calcification [19]-[21] and were reported to decrease calcification in the corals Pocillopora damicornis [22] and even entire patch reefs [23]. However, this phosphate dust has also physical effects in reducing the light intensity and increasing sedimentation, both of which have been shown to have deleterious effects on reefs [24].

Coral reefs in Nauru Island in the north pacific were threatened by phosphate export industry, which has been operated for 100 years [25]. Widespread phosphate mining in the Pacific Islands has destroyed vast spaces of the coral reef [26].

Several studies on phosphate pollution in the Gulf of Aqaba near the Phosphate Terminal (PT) were conducted in the early 1990s [27]-[30]. High traces of uranium compared with those reported from other regions in the world as well as high levels of radioactivity in core and beach sediments at the Phosphate Terminal location were reported and were referred to the phosphate dust during shipment [31]. High levels of radioactive isotopes exist in sediments in the Phosphate Loading Berth site in the Gulf of Aqaba, which are much higher than those reported from other regions around the world (at least by a factor of 2) and from the other locations in the Gulf of Aqaba (by at least a factor of 3) [31].

The destruction of corals by pollution and other anthropogenic factors leads to the eventual threat to many reef-associated species dependent on living corals for food, shelter, and refuge from predators [32].

The Stylophora pistillata is among the important coral species and known to be the fastest of the scleractinian corals that are common in the Gulf of Aqaba as well as in the Red Sea. It is also very suitable for research due to being sampled without major damage to the colony [33] [34].

In this study, calcium composition of Stylophora pistillata corals from Phosphate Terminal site in the Jordanian Gulf of Aqaba, where phosphate dust is the main pollutant, was investigated. This paper reports remarkable findings including low calcium observation and microstructure alteration in samples of coral skeleton taken from Phosphate Terminal (PT) compared to samples from the MSS control site. The coral samples were characterized by energy-dispersive X-ray spectroscopy (EDX) and Scanning Electron Microscopy (SEM) for the analysis of calcium in the skeleton and its microstructure investigation, respectively.

\section{Materials and Methods}

Small fragments of the model branching coral Stylophora pistillata were cultured in a mid-water floating nursery along the Jordanian coast of Gulf of Aqaba [35]. The fragments developed into small colonies to be used as bio-indicator for marine pollution in the selected sites.

Coral samples were collected from the nurseries in the Phosphate Terminal (PT) site and Marine Science Station (MSS) as marine protected area for control samples (Figure 1). 


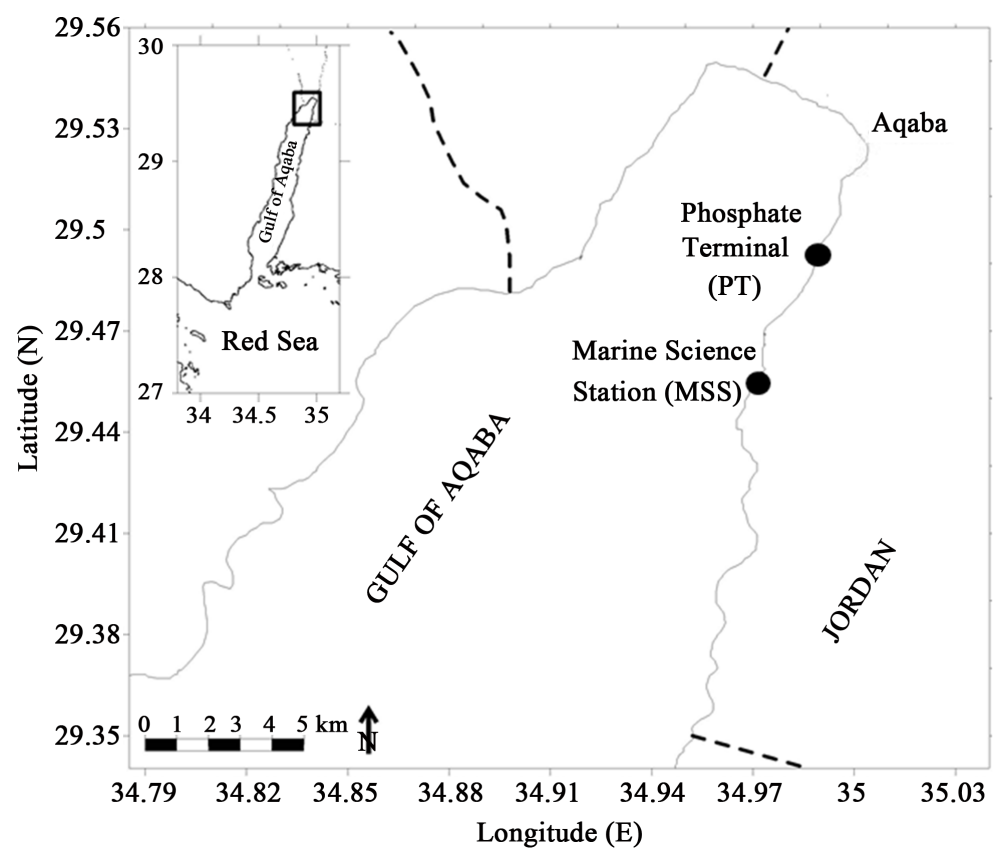

Figure 1. Map of the Gulf of Aqaba. Indicated are the Phosphate Terminal (PT) and Marine Science Station (MSS) sites where corals for this study were collected.

Phosphate Terminal (PT) lies about $3 \mathrm{~km}$ south of Aqaba city (Figure 1) and is the single port for loading and exporting phosphate ore in Jordan while MSS is located about $10 \mathrm{~km}$ south of the city of Aqaba near to the passenger's port.

Coral samples were cut perpendicular to the skeletal growth using low speed diamond saw (BUEHLER Isomat, Germany) and cross section surfaces were further polished using ethyleneglycol lubricant to provide a flat surface that was coated with Au for the SEM imaging.

Field-Emission Scanning Electron Microscope (JEOL JSM-7500F) with an Oxford Instruments detector was used for performing the EDX analysis to measure the elemental content in the coral samples and their corresponding emission spectra, as well as acquiring SEM images for the cross section of each sample.

EDX analysis usually involves the generation of an X-ray spectrum from the entire scan area of the SEM, which shows the counts of X-rays received and processed by the detector and the energy level of those counts. The EDX instrument software associates the energy level of the X-rays with the elements found in the scan area.

\section{Results and Discussion}

Selected EDX spectra from samples of both locations: MSS and PT, are shown in Figure 2 and Figure 3, respectively. The EDX spectra contain peaks of each element that exist in the focused area. The recorded spectra from all samples showed presence of $\mathrm{Ca}, \mathrm{C}$, and $\mathrm{O}$, but for the MSS samples it contains additional trace elements. However, weak calcium peaks from the PT samples compared to the MSS samples can be well recognized. From these spectra, quantitative analysis indicating the weight percent (wt\%) of each element was calculated and presented using Oxford Instruments software.

The quantitative elemental analysis of calcium in addition to oxygen and carbon in coral samples collected from the PT and MSS sites were averaged and presented in Table 1. The EDX elemental quantitative analysis shows that coral samples from the Phosphate Terminal (PT) were poorly mineralized; having very low Ca concentration of only $2.56 \%$, which is around $12 \%$ of the average in the MSS control sample (21.95\%).

Phosphate enrichment in seawater is known as inhibitor of calcification in corals and coralline algae as well [36] [37]. Phosphate is reported to causes a 36\% inhibition of calcification in Stylophora pistillata at relatively low phosphate concentrations in seawater, and stops it completely (99\%) at high concentrations [38].

Thus, low calcium concentrations in the PT samples can be directly related to hindered calcification due to phosphate particles deposited in seawater from the phosphate dust that diffused during ships' loading processes. 


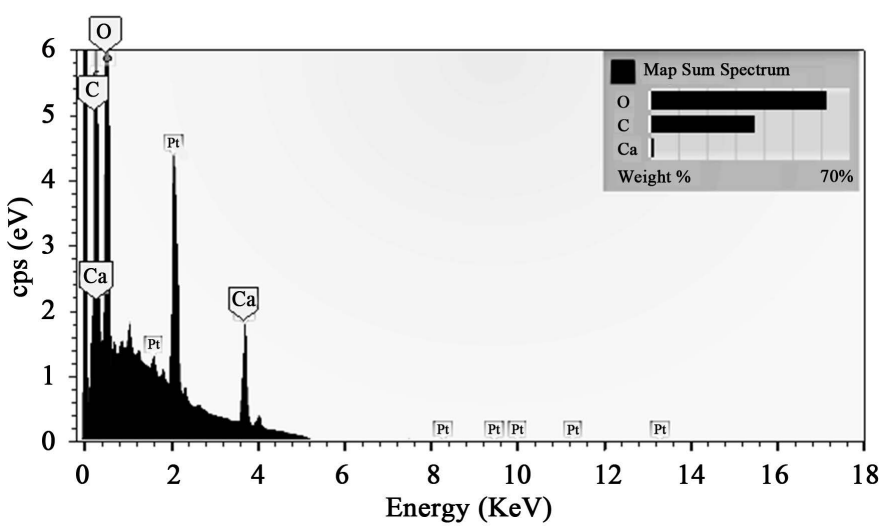

Figure 2. EDX spectrum of the elemental analysis of the PT coral cross section surface (y-axis is magnified).

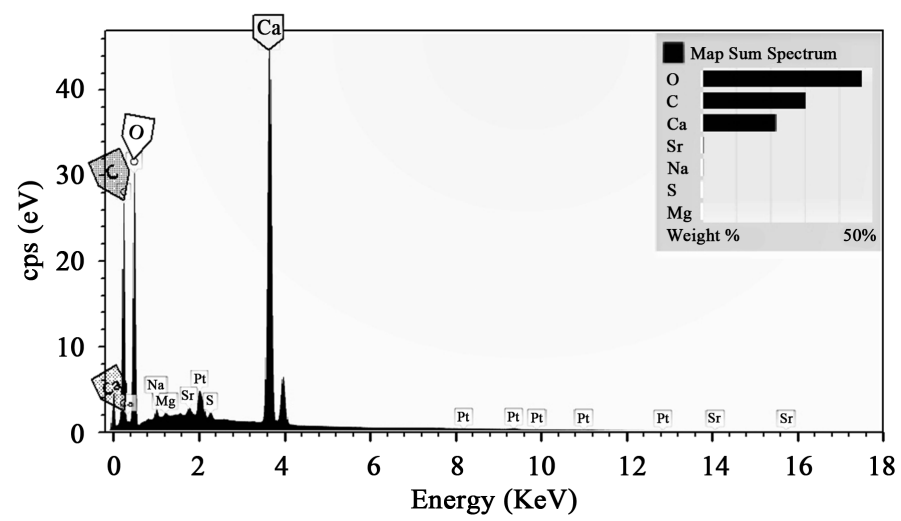

Figure 3. EDX spectrum of the elemental analysis of the MSS coral cross section surface.

Table 1. Concentrations of Ca, O, and C elements (wt\%) in coral samples from the PT and MSS sites.

\begin{tabular}{cccc}
\hline & Ca (wt \%) & C (wt \%) & O (wt \%) \\
\hline PT & $\mathbf{2 . 5 6} \pm \mathbf{1 . 1 1}$ & $35.52 \pm 1.28$ & $61.92 \pm 0.19$ \\
MSS & $21.95 \pm 2.55$ & $31.31 \pm 2.23$ & $45.50 \pm 2.55$ \\
\hline
\end{tabular}

Phosphate pollution has been implicated as a contributor to the decline of reef ecosystems in the Gulf of Aqaba, an area stressed by both oil and phosphate pollution [14] [39] [40]. Inhibition of calcification due to phosphate pollution is also known a major problem for the natural patch reef on the Great Barrier Reef reducing growth by $43 \%$ [23] and in Nauru Island in the north pacific [25].

Walker and Ormond (1982) found that phosphate spillage in the Gulf of Aqaba during loading of phosphate materials and the discharge of sewage is responsible for increasing the death rate of Stylophora pistillata coral. However, Loya (1965) has reported tolerance of coral species Stylophora pistillata to the phosphate [41].

The environmental impacts of the deposited phosphate dust on marine ecosystem include not only siltation of the coral reef and depression of coral growth [42], but also increasing suspended solids and water turbidity, reduction of water clarity and light penetration [43]. Reduced light, excess phosphate and sedimentation is responsible for reduced calcification and increased mortality of corals [37].

The coastal area of the Phosphate Terminal (PT) site in the Gulf of Aqaba contains high sedimentation rate and fine grain size attributed to deposition habitat that receives phosphate particles lost during shipment [44], whereas the Marine Science Station (MSS) site shows the highest calcium carbonate and organic nitrogen concentrations [44]. 
In Table 1, PT samples contained also higher amounts of $\mathrm{O}$ and $\mathrm{C}$ elements which are more than that in samples from the MSS control site (Figure 4). The average combined concentration of $\mathrm{O}$ and $\mathrm{C}$ elements in corals from PT site is $97.44 \mathrm{wt} \%$ whereas for the MSS samples it was $76.81 \mathrm{wt} \%$; i.e. $20 \%$ less. On the other hand, the SEM images of the cross section from samples of the PT (Figure 5 left) exhibited remarkable difference in the microstructure features of their skeleton compared to that from the MSS control site (Figure 5 right). The ceramic-like surface of the MSS samples' cross section resembled mineralized textured surface, which reveals that aragonite is the major constituent in their coral skeleton, whereas the SEM image from the PT site samples showed alteration of the microstructure due to dominance of organic fibers in the skeleton.

Results strongly suggest that coral samples from the PT site contain higher amounts of organic matter which is expected due to the role of phosphate in enhancement of coral zooxanthellae photosynthesis that is responsible for the synthesis of organic matrix of the skeleton [45]. It was also reported that high organic carbon content and high total phosphorus concentration were observed at the Phosphate Terminal (PT) compared to the MSS site [44].

Earlier elemental analysis study on corals from different sites along the Jordanian coast of the Gulf of Aqaba, showed that coral samples from the PT site contain in addition to low calcium concentrations, considerable amounts of trace elements like $\mathrm{Ni}$, and $\mathrm{Na}$ [46].

\section{Conclusion}

Corals that are exposed to phosphate dust during exportation process suffered from very low calcium concentrations in their skeleton. This can be attributed to the well-known inhibition process of calcification by increase of phosphate concentrations in surrounding seawater at the time the corals were formed. Higher organic matrix was found to dominate the structure composition, which is also as a result of phosphate pollution. Coral skeleton mi-

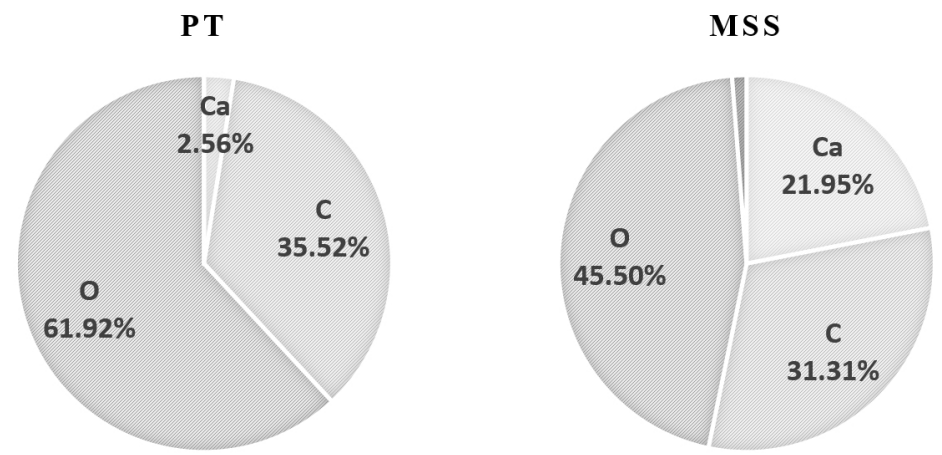

Figure 4. Pie chart representation of Ca, O, and C elements concentrations (wt\%) in coral samples from the PT and MSS sites.
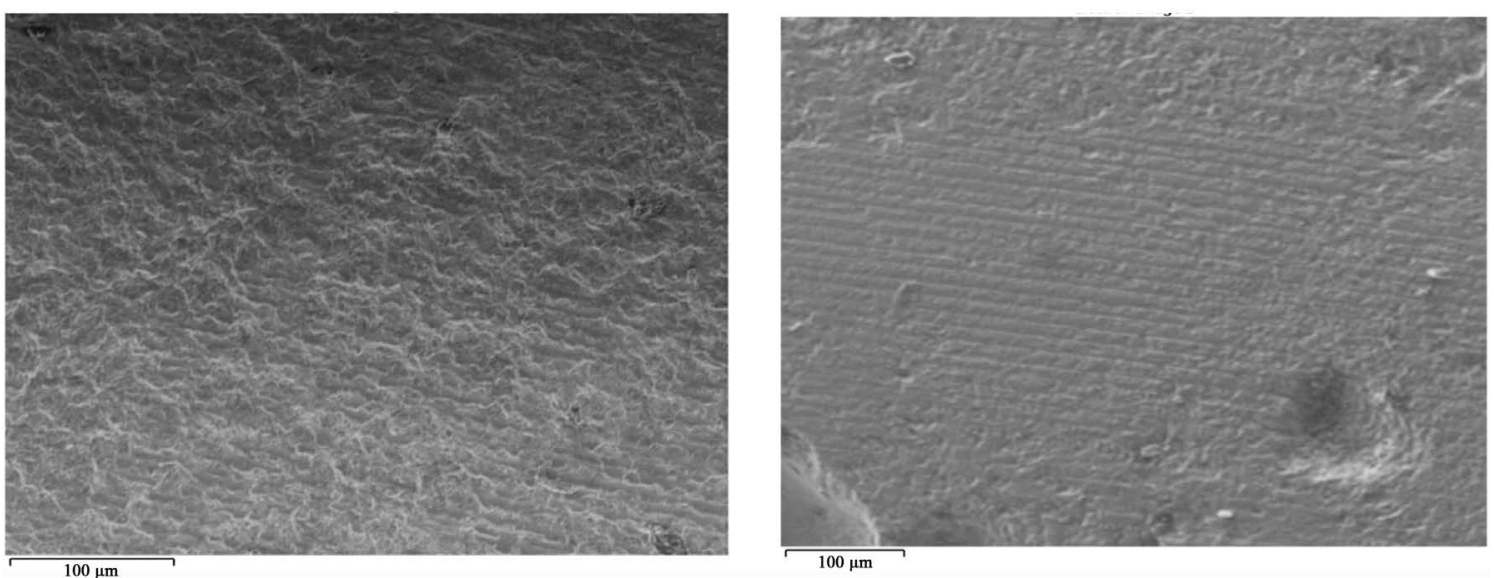

Figure 5. SEM images of coral samples from Phosphate Terminal (PT) site (left) and from the Marine Science Station (MSS) site (right). 
crostructure alteration was also recognized in SEM images presenting the view of organic matrix rather than mineral composition as a result of the phosphate dust. Further elemental analysis and microstructure studies could be conducted on other coral species and several skeletal organisms that live in the Phosphate Terminal coastal site in order to find out their response to phosphate pollution.

\section{Acknowledgements}

The author is indebted to Prof. Fuad Al-Horani for providing the coral samples used for this study. Many thanks to Susann Weichold and Heike Runge of the SEM lab at the Max-Planck Institute for Colloids and Interfaces (MPIKG), Germany for their support and help during the measurements. Also we are thankful to divers Ali Al-Njadat and Omar Al-Momany for collecting the coral samples used in this study.

\section{References}

[1] Johannes, R.E. (1972) Coral Reefs and Pollution. In Ruivo, M., Ed., Marine Pollution and Sea Life, Fishing News (Books), London.

[2] Bryant, D.G., Burke, L., McManus, J. and Spalding, M. (1998) Reefs at Risk: A Map-Based Indicator of Threats to the World's Coral Reefs. World Resources Institute, Washington DC.

[3] Spalding, M., Ravilious, C. and Green, E.P. (2001) World Atlas of Coral Reefs. University of California Press, Berkeley.

[4] Smith, S.V., et al. (2003) Humans, Hydrology, and the Distribution of Inorganic Nutrient Loading to the Ocean. Bioscience, 53, 235-245. http://dx.doi.org/10.1641/0006-3568(2003)053[0235:HHATDO]2.0.CO;2

[5] Tilman, D., Fargione, J., Wolff, B., D’Antonio, C., Dobson, A., Howarth, R., Schindler, D., Schlesinger, W.H., Simberloff, D. and Swackhamer, D. (2001) Forecasting Agriculturally Driven Global Environmental Change. Science, 292, 281-284. http://dx.doi.org/10.1126/science.1057544

[6] Al-Horani, F.A., Al-Rousan, S.A., Al-Zibdeh, M. and Khalaf, M.A. (2006) The Status of Coral Reefs on the Jordanian Coast of the Gulf of Aqaba, Red Sea. Zoology in the Middle East, 38, 99-110. http://dx.doi.org/10.1080/09397140.2006.10638171

[7] Gosheh, A., Doudeen, F., Salameh, A. and Kalbouneh, R. (1991) Jordan Phosphate Rock. Third International Fertilizer Seminar, Amman, 1991.

[8] Phosphate Loading (Aqaba), 2008.

[9] Sandler, D. (1993) Protecting the Gulf of Aqaba: A Regional Environmental Challenge. Environmental Law Institute, Washington DC.

[10] Bemert, G. and Ormond, R. (1981) Red Sea Coral Reefs. Kegan Paul International, London, Boston.

[11] Freemantle, M.H., Hulings, N., Mulqi, M. and Watton, E.C. (1978) Calcium and Phosphate in Jordan Gulf of Aqaba. Marine Pollution Bulletin, 9, 79-80. http://dx.doi.org/10.1016/0025-326X(78)90454-X

[12] Grobler, D.C. and Davies, E. (1979) Availability of Sediment Phosphate to Algae. Water SA, 5, 114-122.

[13] McColl, R.H.S. (1975) Availability of Soil and Sediment Phosphorus to a Planktonic Alga. New Zealand Journal of Marine and Freshwater Research, 9, 169-182. http://dx.doi.org/10.1080/00288330.1975.9515557

[14] Fishelso, L. (1973) Ecology of Coral Reefs in Gulf of Aqaba (Red-Sea) Influenced by Pollution. Oecologia, 12 , 55-67. http://dx.doi.org/10.1007/BF00345470

[15] Borowitz, M. (1972) Intertidal Algal Species Diversity and Effect of Pollution. Australian Journal of Marine and Freshwater Research, 23, 73-84. http://dx.doi.org/10.1071/MF9720073

[16] Fitzgerald, W.J. (1978) Environmental Parameters Influencing Growth of Enteromorpha clathrata (Roth) J. Ag. in Inter-Tidal Zone on Guam. Botanica Marina, 21, 207-220. http://dx.doi.org/10.1515/botm.1978.21.4.207

[17] Westlake, D.F. (1963) Comparisons of Plant Productivity. Biological Reviews of the Cambridge Philosophical Society, 38, 385-425. http://dx.doi.org/10.1111/j.1469-185X.1963.tb00788.x

[18] Topping, G. (1976) Sewage and the Sea. In: Johnstone, R., Ed., Marine Pollution, Academic Press, London, $303-351$.

[19] Morse, J.W. (1974) Dissolution Kinetics of Calcium-Carbonate in Sea-Water; V, Effects of Natural Inhibitors and Position of Chemical Lysocline. American Journal of Science, 274, 638-647. http://dx.doi.org/10.2475/ajs.274.6.638

[20] Pokrovsky, O.S. and Savenko, V.S. (1993) The Kinetics of Calcium-Carbonate Nucleation in Seawater-The Role of the Phosphates and the Hydrodynamics of Medium. Okeanologiya, 33, 681-686.

[21] Pytkowic, R. (1973) Calcium-Carbonate Retention in Supersaturated Seawater. American Journal of Science, 273, 515-522. http://dx.doi.org/10.2475/ajs.273.6.515 
[22] Lamberts, A.E. (1974) Measurement of Alizarin Deposited by Coral. The Second International Coral. The Great Barrier Reef Waters, Department of Zoology, University of Hawaii, Honolulu, 241-244.

[23] Kinsey, D.W. and Davies, P.J. (1979) Effects of Elevated Nitrogen and Phosphorus on Coral-Reef Growth. Limnology and Oceanography, 24, 935-940. http://dx.doi.org/10.4319/lo.1979.24.5.0935

[24] Dodge, R.E. and Vaisnys, J.R. (1977) Coral Populations and Growth-Patterns-Responses to Sedimentation and Turbidity Associated with Dredging. Journal of Marine Research, 35, 715-730.

[25] Sulu, R. (2007) Status of Coral Reefs in the Southwest Pacific, 2004. IPS Publications, Suva.

[26] Weeramantry, C.G. (1992) Nauru: Environmental Damage under International Trusteeship. Oxford University Press, Melbourne, New York.

[27] Abuhilal, A. (1993) Observations on Heavy-Metal Geochemical Association in Marine-Sediments of the Jordan Gulf of Aqaba. Marine Pollution Bulletin, 26, 85-90. http://dx.doi.org/10.1016/0025-326X(93)90096-3

[28] Abuhilal, A.H. (1985) Phosphate Pollution in the Jordan Gulf of Aqaba. Marine Pollution Bulletin, 16, 281-285. http://dx.doi.org/10.1016/0025-326X(85)90567-3

[29] Abuhilal, A.H. (1994) Effect of Depositional Environment and Sources of Pollution on Uranium Concentration in Sediment, Coral, Algae and Seagrass Species from the Gulf of Aqaba (Red-Sea). Marine Pollution Bulletin, 28, 81-88. http://dx.doi.org/10.1016/0025-326X(94)90543-6

[30] Abuhilal, A.H. and Badran, M.M. (1990) Effect of Pollution Sources on Metal Concentration in Sediment Cores from the Gulf of Aqaba (Red-Sea). Marine Pollution Bulletin, 21, 190-197. http://dx.doi.org/10.1016/0025-326X(90)90501-X

[31] Ababneh, Z.Q., Al-Omari, H., Rasheed, M., Al-Najjar, T. and Ababneh, A.M. (2010) Assessment of Gamma-Emitting Radionuclides in Sediment Cores from the Gulf of Aqaba, Red Sea. Radiation Protection Dosimetry, 141, $289-298$. http://dx.doi.org/10.1093/rpd/ncq182

[32] Johannes, R.E. (1975) Pollution and Degradation of Coral Reef Communities. In: Wood, E.J.F. and Johannes, R.E., Eds., Tropical Marine Pollution, Chap. 2, Elsevier Oceanography Series, Elsevier, Amsterdam, 13-50.

[33] Loya, Y. (1972) Community Structure and Species Diversity of Hermatypic Corals at Eilat, Red Sea. Marine Biology, 13, 100-123. http://dx.doi.org/10.1007/BF00366561

[34] Loya, Y. and Slobodkin, L.B. (1971) The Coral Reefs of Eilat (Gulf of Eilat, Red Sea). In: Yonge, M. and Stoddart, D.R., Eds., Regional Variation of Indian Ocean Coral Reefs, Academic Press, New York, 117-140.

[35] Al-Horani, F.A. and Khalaf, M.A. (2013) Developing Artificial Reefs for the Mitigation of Man-Made Coral Reef Damages in the Gulf of Aqaba, Red Sea: Coral Recruitment after 3.5 Years of Deployment. Marine Biology Research, 9, 749-757. http://dx.doi.org/10.1080/17451000.2013.765582

[36] Simkiss, K. (1964) Phosphates as Crystal Poisons of Calcification. Biological Reviews, 39, 487-504. http://dx.doi.org/10.1111/j.1469-185X.1964.tb01166.x

[37] Walker, D.I. and Ormond, R.F.G. (1982) Coral Death from Sewage and Phosphate Pollution at Aqaba, Red-Sea. Marine Pollution Bulletin, 13, 21-25. http://dx.doi.org/10.1016/0025-326X(82)90492-1

[38] Yamashiro, H. (1995) The Effects of Hebp, an Inhibitor of Mineral Deposition, Upon Photosynthesis and Calcification in the Scleractinian Coral, Stylophora-Pistillata. Journal of Experimental Marine Biology and Ecology, 191, 57-63. http://dx.doi.org/10.1016/0022-0981(95)00045-S

[39] Fishelson, L. (1977) Stability and Instability of Marine Ecosystems, Illustrated by Examples from Red-Sea. Helgolander Wissenschaftliche Meeresuntersuchungen, 30, 18-29. http://dx.doi.org/10.1007/BF02207822

[40] Loya, Y. (1975) Possible Effects of Water-Pollution on Community Structure of Red-Sea Corals. Marine Biology, 29, 177-185. http://dx.doi.org/10.1007/BF00388987

[41] Loya, Y. (1976) Red-Sea Coral Stylophora pistillata Is an R-Strategist. Nature, 259, 478-480. http://dx.doi.org/10.1038/259478a0

[42] Hawkins, J.P., Roberts, C.M. and Adamson, T. (1991) Effects of a Phosphate Ship Grounding on a Red-Sea Coral-Reef. Marine Pollution Bulletin, 22, 538-542. http://dx.doi.org/10.1016/0025-326X(91)90892-V

[43] Hashwa, F. (1980) The Phosphate Pollution in the Gulf of Aqaba. Proceedings of the Symposium on Coastal and Marine Environment of the Red Sea, Gulf of Aden and Tropical Western Indian Ocean, Khartoum, 9-14 January 1980, 109-124.

[44] Badran, M.I. and Al Zibdah, M.K. (2005) Environmental Quality of Jordanian Coastal Surface Sediment, Gulf of Aqaba, Red Sea. Ambio, 34, 615-620. http://dx.doi.org/10.1579/0044-7447-34.8.615

[45] Jones, O.A. and Endean, R. (1973) Biology and Geology of Coral Reefs. Academic Press, New York.

[46] Al-Sawalmih, A., Al-Horani, F., Al-Rousan, S. and Khoshman, J. (2016) Elemental Analysis of the Branched Coral Stylophora pistillata Nursed along the Jordanian Coast of Gulf of Aqaba. (In Preparation) 